\title{
REFLECTING TRANSLANGUAGING IN CLASSROOM PRACTICES: A CASE STUDY
}

\author{
Magdalena Kartikasari Tandy Rerung \\ Universitas Bunda Mulia \\ mrerung@bundamulia.ac.id
}

\begin{abstract}
Strategies comes from Greek word "strategia" which means the art of planning and directing. Regarding to language learning, a strategy is used to achieve their goal depends on the skill they obtain. Specifically speaking skill is one of the productive skills that can be a challenging thing for university students who majored in English. Besides vocabulary, other element that support their language production is motivation. Avoiding in using Bahasa Indonesia can make them unmotivated sometimes. If this is the case, therefore the students might be passive learners in the classroom. Translanguaging is a strategy in language learning that can motivate students keep learning the language by combining their first language with the foreign one. The following case study is intended to observe how do students use translanguaging. The study was a class observation involving four students majored in English Language and Culture Program at Bunda Mulia University. They were in fourth semester and enrolling in the Listening and Speaking Class. Apparently the result shows that students who use their first language in the speaking task help them in delivering information and telling stories.
\end{abstract}

Keywords: translanguaging strategies, speaking skill, language learning

\begin{abstract}
ABSTRAK
Kata "strategi" berasal dari bahasa Yunani "strategia" yang artinya perencaan dan pengarahan, Sesuai dengan makna dari kata tersebut dalam proses pembelajaran bahasa, maka sebuah strategi diperlukan agar mahasiswa dapat mencapai tujuan pembelajaran tersebut melalui keterampilan berbahasa yang mereka miliki. Secara khusus, ketrampilan berbicara bahasa Inggris merupakan salah ketrampilan yang sifatnya produktif. Bagi mahasiswa yang memiliki kemampuan tebatas hal ini merupakan suatu tantantan sendiri, terlebih ketika mereka mengambil jurusan Bahasa dan Budaya Inggris. Selain kosakata, faktor lain yang mendukung proses pembelajaran mereka adalah motivasi. Ketika mereka dilarang menggunakan bahasa Indonesia dalam kelas, hal ini dapat membuat motivasi belajar mereka berkurang akibatnya mereka cenderung menjadi pembelajar yang pasif. Translanguaging dalam hal ini merupakan salah satu strategi yang dapat memotivasi mereka dengan cara menggabungkan dua bahasa selama proses pembelajaran berlangsung. Studi kasus berikut bertujuan untuk mengamati bagaimana para mahasiswa menggunakan strategi translanguaging ini. Studi ini merupakan observasi kelas yang melibatkan empat mahasiswa jurusan Bahasa dan Budaya Inggris di Universitas Bunda Mulia. Mereka tergabung dalam kelas Listening and Speaking. Hasilnya ternyata menunjukkan bahwa mahasiwwa yang menggunakan bahasa Indonesia dalam kelas justru membantu mereka untuk berkomunikasi dalam bahasa Inggris seperti menyampaikan informasi dan berbagi cerita.
\end{abstract}

Kata Kunci: strategi translanguaging, keterampilan berbicara, pembelajaran bahasa

\section{LITERATURE REVIEW}

Even though English has been taught in Indonesian schools as part of the curriculum however English is only used institutionally and leave the language at school every time they back into their routine activities. Since English is still considered as a foreign language in Indonesia, therefore students who want to study abroad will likely to take English courses intensively, either in Indonesia or in the country that they would likely to apply for studying. Several approaches and learning strategies are applied to study English as means of communication.
First by using monolingual strategy, where they were instructed to use English exclusively without the interference of first language (L1) however this strategy will make the students with lesser English ability getting more passive and they their language skill might not develop properly. Second strategy is by being bilingual where the students may mix both English and their first language to communicate. Here they can do the code mixing whenever they do not understand how to state some words in English. 
However, learning foreign language is different than acquiring where natural and behavior enforcement is involved. Their first language cannot be separated even though they have learnt the foreign language intensively and exclusively. This language should be used together to access information and involve in the communication.

Thre are some definitions that describe translanguaging (taken from Park, 2012) such as flexible bilingualism (Creese \& Blackledge, 2010), polylingualism (Jørgensen, 2010), metrolingualism (Otsuji \& Pennycook, 2010), and code meshing (Michael-Luna \& Canagarajah, 2007; Canagarajah, 2011). Finally it comes to translanguaging which was first mentioned by the Welsh educator, Colin Williams (1996) and developed by García (2009) and many others (García \& Velasco, Translanguaging and the Writing of Bilingual Learners, 2014). García (2009) expanding the term into processes where students incorporate the language practices of school of their own linguistic repertoire freely and flexibly. For example students may use their first language either in productive or receptive use and giving them liberty in exposing their knowledge. She regards it as a strategy that bilinguals use to make meaning, shape their experiences, gain understanding and knowledge, and make sense of their bilingual worlds through the everyday use of two languages: "translanguaging is indeed a powerful mechanism to construct understandings, to include others, and to mediate understandings across language groups (García, 2009).

Translanguaging is seen as a tool in a pedagogical approach to negotiate meaning in classroom settings, particularly multilingual ones. The process mostly occurred in learners' productive and receptive language skills (García, 2014). Productive and receptive language skills are both used to gain information and communicating. This is where languages are working together to form the knowledge. Receptive skills such as listening and reading whereas Productive skills such as speaking and writing. Learners have the options to use their first languge (L1) in order to gain the knowledge and expose their second or foreign language (L2) to perform their ideas. The preferences would be depend on the learners' language ability.
Research in translanguaging was once conducted in order to find out its development in the academic writing bilinguals. It reviews the emerging literature on learning and teaching theories of translanguaging and presents theoretical understandings of biliteracy development and specifically on the teaching of writing bilingual learners. Based on the five written text produced by young bilingual writers, the translanguaging is used in the planning, drafting, and production stages. Translanguaging in writing is here proposed more as a self-regulating mechanism in which bilingual students can engage, rather than pedagogy to be used in the teaching of writing itself. The article shows a clearer result where translanguaging approach has the most potential in constructing academic language comopared to monolingual and bilingual ones. (García \& Velasco, 2014)

Another study on translanguaging was conduced by Adamson \& FujimotoAdamson (2012) which investigated language advising in a self-access center (SAC) in a Japanese university. The aim is to encourage translanguaging into 'English-only' language policy. Based on the interviews and questionaires, students showed positive result toward the translanguaging and give them a self-access knowledge.

The following study attempts to find out how do the students apply translanguaging in the classroom especially in the spoken classroom.

According to Baker (Colin, Jones, \& Lewis, 2012), there are four potential educational advantages to translanguaging, those are promoting a deeper and fuller understanding of the subject matter; helping the development of the weaker language; facilitating home-school links and cooperation; helping the integration of fluent speakers with early learner.

In line with the advantages above, the following study aims to introduce translingual strategies for those who never think about the possible to learn and adjust language easier. It also hopefully can narrow down the gap that the Indonesian learners may face when they join the overseas universities during their first year. Furthermore the result may be a model for other foreign learners to apply this strategy by using their own languages. 


\section{TRANSLANGUAGING AND LANGUAGE SKILLS}

The pattern use of translanguaging strategies can be seen in some language learning skills either productively or receptively. Garcia and Kano (2014) observe some practices in the writing skills among bilingual American Japanese students. The study found out that the students use Japanese whenever they couldn't think the words in English. The practice used when they make a draft of academic writing. They further argue that the first language usage help them to deepen the understanding of what is to be written; and hence can give a coherent and concise written essay.

Furthermore, Martinez-Roldan (2015) elaborates the translanguaging practices to bilingual students in secondgrade level. The students were observed for their reading skill. The result shows that it encourages interconnectivity of languages around a variety of texts (taken from Joseph, 2015).

Based on my previous research on evaluating translingualism in the classroom, there are some specific strategies that they use in the classroom, the result is shown below:

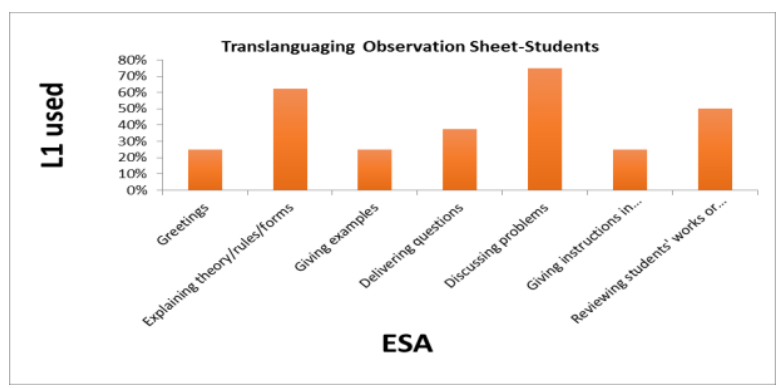

Most practices of translingualism is shown whenever the students having a discussion and explaining specific topic either to their lecturers or among themselves. Having discussion in this case need to involve longer sentence production, for students this process may be more difficult because it was a multi process of thinking. First they have to think the concept next would be how to explain it in English. For students who are more successful, this is not too complicated however for the students who are lack of proficiency, having an English discussion might be a challenging activity for them.
Therefore, they prefer to speak about concepts in English even though the reading material is in English.

\section{RESEARCH DESIGN}

The study applied a qualitative design with an observation approach. The total students being observed were 4 and they were being monitored during the class. These students were at their second semester and their proficiency level is between low to high intermediate level. The participants was joining a listening speaking class with the focus only on their spoken language. Furthermore for the procedure, the lecturer design several and ask them to choose which topic that they are most familiar with. The data were gathered with an audio recording application and the duration was two minutes for each of the topic. For the result, the recoding data then being transcribed and highlighted for the translanguaging practices.

\section{FINDINGS}

Based on the result the following showed how do the students attempt to switch the language into Bahasa Indonesia even though the usage was considered minimal.

\section{Student 1 \\ Topic :Transportation \\ Duration: $121 \mathrm{~s}$}

About online transportation and manual transportation I..I.. personally travel online transportation because it is easier and it's cheaper than manual transportation like for example if I went to grand indonesia with grabcar I only pay like uhm... 35 ribu berapa ya? thirty thousand rupiah but if I use bluebird I can pay for like fifty thousand rupiah and ehh apa, and with grabcar or grabbike uh I can order it much much easier than the transportation aduh apa lagi nih. and about the manual transportation I don't really like it because I watched in the news that they force other people to demo with them and my mom has a friend and temannya mama gua. my friends mom has a daughter she was on the road when the demo happened and the taxi driver force her to join the demo she doesn't want to join and her head was hit 
by a taxi driver with a helm helmet...that's it thank you.

The result above shows how Indonesian is being used several times during her speech. If we take a look in general, it may look as a lack of vocabulary knowledge. However shifting several phrases into L1 apparently help her to start speaking with even in better fluency. The speaker here is actually a nervous student and every time she has difficulties in speaking English, she tends to stop or laugh nervously. Therefore, when I told her that she could use Indonesian whenever she needs to eventually it adds her confidence. For example she said in Indonesian when talking about numbers it order to re-think it in English. Apparently it helps her and even she could mention other number without feeling hesitate. For other phrases in Indonesian, used just only as gap filler while she thinks for better words.

\section{Student 2 \\ Topic: Shutter Island \\ Duration: 2'11}

It's an older guy whose name Teddy ya Teddy and put his son into a rumah sakit jiwa apa sih? (a friend answered: asylum) into asylum in an island and he went with his friends for...menyelidiki apa ya? ( a friend answered: to investigate) to investigate a case in that island, in that asylum. In that asylum, the case that...one of the patient in the asylum is missing, is missing and Ted and his friend investigate about why she was missing. And in that, eh.. she left..eh..many, petunjuk.petunjuk..petunjuk. She left many clues uhm and Ted and his friends investigate..uhm.tengah-tengahnya apa ya..pausing.. In the end of the story actually the one who was the patient in the asylum.

From the previous result, it is shown that a friend helped her to translate the words that she intended. As in monolingual approach, the following error should be avoided since it probably would reduce the student foreign language skill. Another reason that the student would rely more on the L1 use and choose the easy part in communicating. Therefore the teacher sometimes pushes the students to avoid switching to L1 in any circumstances. Some cases even make the students to rely their gestures in communicating. On the contrary, the student's friend support showed a positive value for her. By giving her the answers, she then become more confident and try to continue her explanation further. During the last part of her speech, she repetitively spoke an Indonesian word in order to get the correct English word. Therefore instead of asking her friend, she then trusted herself even though she has to repeat the L1 word as the trigger for the $\mathrm{L} 2$ word.

\section{Student 3}

Topic: Favorite food

Duration: 2' 25

.uh.food is one of thing that I like. and I eat food for life, If I, if I need to choose whether food western or eastern I prefer to western because western is common and I can find western food in Indonesia easily like in McDonalds, Burger King, Pizza Hut, and so on. I don't really like eastern food because it contain some bumbu apa some strange ing..ingredients..like mmm aduh ya..like something smell bad.uh..ya like curry but I like kebab but not curry, curry is smell bad. what else..uh.. talk about the food price, I think the western is cheaper than the eastern..eh..I don't think so too, it depends it depends where you buy. I buy I buy kebab in canteen it's just sixteen thousand but I buy burger with the soda and french fries it cost twenty five thousand rupiah in Mc

Donald ... and ...thank you.

In the above case, the translanguaging may not appear as many as before, but interestingly there is a translaguanging in the language pattern. If we look of the phrase food western, where she chose Indonesian word structure for English meaning. The similar pattern also shown in the utterance $I$ eat food for life where L1 pattern is reflected here. The pattern is better viewed as the process of translanguaging rather than some ungrammatical mistakes. Furthermore the students also use L1 as an attempt to trigger the L2 word that she intended to. Similar with the student 2 , she used repetitive technique in order to help herself. Other than that, she also used L1 as fillers while she thinks of the next idea. 


\section{Student 4 \\ Topic: Online Transportation \\ Duration: 2 minutes}

Ok, I love to use transportation online because I think it's more cheaper and it's more uh..it's more.. uh....it don't take a long time to go to a place uh because we don't need to waiting long. I usually go home by train and it take take a long time and now when uh..uh... when..laughing..(asking the teacher) sekarang udah ada- apa? (Bahasa Inggrisnya)... now we have I use gojek and I use gojek and it take uh lebih cepet apa..(Bahasa Inggrisnya)? short time. Usually if I use train it takes about two until three hours to arrive at home. But now when I use gojek it just take one and a half hour .... uh....uh... and it just..uh... about twelve thousand rupiahs

For this case, the student use Indonesia and asked the teacher's help for the English words. The teacher then helped her by giving some clues in English words, and interestingly it helped her. Only a word clue only she could construct a longer sentence. The teacher in this can assist the student with even using the L1 without being worry that the students couldn't be able to find the meaning in English. Sometimes in exclusive L2 teaching, the students feel hesitate in asking the teacher help, especially in finding the exact meaning in English. On the other hand, the teacher also sometimes instructs students to keep talking in English. The result will be a missing gap in between where the students is having lack of vocabulary but the teacher just stay quiet.

\section{DISCUSSIONS AND SUGGESTIONS}

Translanguaging is seen as students practices in filling the gap between their foreign language skills with their first language. Joseph elaborates translanguaging as a skill relates to multilingual proficiencies and the simulatenous listening, speaking, reading and writing of language users in different context. He also added that the strategies applied by teachers in the classroom covered some main goals, namely "(1) the contextualization of key words and concepts, (2) the development of metalinguistic awareness, (3) and the creation of affective bonds with students (Garcia, Flores, and Woodley, 2012 taken from Joseph, 2015).

Furthermore, based on the results, it is shown that the students use L1 or Bahasa Indonesia for several purposes. First is to create an affective situation where the students feel nervous every time he or she must speak in English. There might be several reasons rely to this situation, such as afraid the he or she will likely to produce ungrammatical sentences, or maybe as the result of becoming a center of attention so he or she worries if other students laugh at him/her.

The second strategy found is "by asking an English words(s) to a friend". Interestingly in monolingual approach every time a student faces some circumstances where English is exclusively used, getting help from other students is strongly prohibited. The reason will rely on the teacher's belief that the student would not be an independent learner later. However based on this finding, asking for a help from the student's friend does not affect her language production in fact it helps her to construct the next sentences.

The third translanguaging strategy apparently shown in the form of L1 grammatical structure and appeared in the L2. For example the student used "food western" instead of "western food", also in the phrase "curry is smell bad" where it should be "curry smells bad". If it is viewed from the perspective of English grammar, both phrases are mistakenly applied however in the translanguaging strategies, it is viewed as a process of the student's understanding in using the words. The teacher in this case may correct or may not since the student probably understand the error but she was interfered with her first language used so she couldn't avoid it.

The fourth translanguaging strategy used by the students is "by asking to the teacher an English word", in this part the student needs to confirm what she has in mind but does not sure whether it was correct or not. The teacher, in this case, provides the answer that she needed and as the result she became more confident as if it was a support for her. Similar with the strategy "asking help from a friend" here the student feels like she was supported and she even able to continue her statement after. 
As quoted from Joseph (2015) that translanguaging basically how do students do with language, such as to understand and perceive the language. Furthermore Oostendorp \& Anthonissen (2014: p.73 quoted (Joseph, 2015)) describe translanguaging as the "heteroglossic practices used by students in learning contexts". There are probably ways that were being avoided in the past because the fear of "too much relying on L1" would slow down the usage of L2. This assumption might have to be reconsidered, since based on several findings it is shown that translanguaging strategies help students to increase their confidence and decreasing their uncomfortable in using the language. In speaking skill, the affective part is somewhat influence students learning process. Therefore, as teachers, it is suggested to allow the some translanguaging practices in the classrooms to offer students another better way in the language learning process.

\section{REFERENCES}

Adamson, J., \& Fujimoto-Adamson, N. (2012, March). Translanguaging in Self-Access Language Advising: Informing Language Policy. Studies in Self-Access Learning Journal, 1(3), 59-73.

Colin, B., Jones, B., \& Lewis, G. (2012). Translanguaging: origins and development from school to street and beyond . Educational Research and Evaluation, 641-654.

García, O. (2014). TESOL Translanguaged in NYS: Alternate Perspectives. NYS TESOL JOURNAL, 2-10.

García, O., \& Velasco, P. (2014). Translanguaging and the Writing of Bilingual Learners. Bilingual Research Journal, 6-23.

Joseph, D. I. (2015, November). A Sociolinguistic Analysis of the Effective Translanguaging Strategies of Some First Year Bilingual Students at University of the Western Cape.

Novera, I. A. (2004). Indonesian Postgraduate Students studying in Australia: An Examination of their Academic, Social. International Education Journal, 5(4), 475-487.
Park, M. S. (2012). Code-switching and Translanguaging: Potential Functions in Multilingual Classrooms. Teachers College, Columbia University Working Papers in TESOL \& Applied Linguistics, 13(2), 50-52. 